\title{
HOUSEHOLD AND FAMILY STRUCTURE: A BASELINE STUDY AMONG PRIMARY SCHOOL LEARNERS IN CHATSWORTH, SOUTH AFRICA
}

\section{Vishanthie Sewpaul, Anitha Pillay}

\section{INTRODUCTION}

This article is based on a study that was designed to understand household and family structures in one designated community in KwaZulu-Natal, South Africa. It discusses the results of a quantitative survey with 328 primary school learners in the Chatsworth area. Before the presentation of the empirical data, a brief history and description of Chatsworth is presented as background to the study.

\section{BACKGROUND TO THE STUDY}

Chatsworth is a large township in Durban, South Africa, which was created as a result of the apartheid government's Group Areas Act, Act No. 41 of 1950 (Union of South Africa, 1950). Apartheid provided the policy framework for the maintenance of minority rule through the institutionalised social, economic, political and legal segregation of South African Whites, African Blacks, Indians and Coloureds.

Chatsworth was established in the late 1960s and early 1970s, and designated for use by the Indian population only, who were removed from their initial areas of occupation as a consequence of racial segregation policies. It has a population of approximately 500000 people and is presently a mixed socio-economic area, which has some necessary facilities such as schools, libraries, a state hospital, a private hospital, clinics, community halls and sports grounds. The majority of the homes are council-built single and attached houses and blocks of flats with the basic amenities. As the economic status of residents improved, many of them renovated and extended their homes. The area largely reflects lower- to middle-income earners. During 2000 Chatsworth was briefly the centre of a social movement known as "the poors", as the developing infrastructure had missed the poorest of the population, mainly as a result of the loss of manufacturing jobs because of the economic liberalisation programme of the self-imposed structural adjustment policy known as Growth, Employment and Redistribution [GEAR] (Desai, 2002). ${ }^{1}$

As a result of migration into urban areas for better educational and employment opportunities, there have been many informal settlements created on the outskirts of Chatsworth. These settlements are characterised by shack-type dwellings and are populated by persons of African Black origin, many of whom are impoverished. The HIV/AIDS pandemic has further impacted on this already disadvantaged community, with the elderly having to raise orphaned and abandoned grandchildren. Exacerbating the challenges in this particular community are the high levels of unemployment; young people are often unskilled and battle to escape poverty.

\footnotetext{
${ }^{1}$ GEAR, rooted in a neoliberal ideology with its emphasis on fiscal austerity, cutback in state expenditure, privatisation of state assets and basic services, casualisation of labour and lowering of trade tariffs (Bond, 2005; Hart, 2002; Sewpaul \& Holscher, 2004), detracts from a structural and social justice approach to community and family living. The very premises of GEAR are based on individualism, corporate competitiveness and profit-making that do not augur well for a country with a professed commitment to social justice and a developmental welfare approach (Sewpaul, 2005). Contrary to expectations of a post-apartheid state, we have exacerbated the inequality of the past, increased unemployment, widened the poverty gap, and we are in the unenviable position of having about the highest rate of HIV/AIDS in the world (Bond 2005; Desai, 2002; Terreblanche, 2002).
} 
Many of the children from these informal settlements attend schools in the Chatsworth area and so would have formed part of the sample for this study.

The caseload at Child Welfare Chatsworth includes abandoned children, orphaned children, children in alternative care, domestic violence and marital and pre-/post-divorce counselling. Social workers in practice have noted an increase in the number of orphaned, abandoned and neglected children who enter the welfare system and who require alternative care placements (Gordhan, 2007). From research such as that of Madhavan (2004) and Whiteside and Sunter (2000) it can be extrapolated that the HIV/AIDS pandemic might be contributing to the increasing number of children who are required to be placed in alternative care.

Data on household structure and its influence on children's lives in the Chatsworth community are not available. Conclusions are often based on Child Welfare caseload statistics and generalisations in the media on the impact of the HIV/AIDS pandemic, increasing divorce rates and rising unemployment. In addition, social workers observe an increase in the number of female-headed households, grandparent-headed households and child-headed households. However, the main problem is that the prevalence of these changes in the Chatsworth area and their influence on children is relatively unknown. This provided the primary motivation for this study. This is the first study, as far as the authors are aware, designed to obtain baseline data on family and household structures in Chatsworth and their influence on primary school learners.

\section{RESEARCH METHODOLOGY}

The study utilised a quantitative method and the descriptive-explanatory research design.

It involved the administration of fairly structured questionnaires to a sample of 328 Grade 7 learners from schools in the Chatsworth area. Stratified and simple random sampling strategies were used. Stratified random sampling was initially used to divide the population to be studied, i.e. Grade 7 learners, into groups according to geographical location. From these groups, one school was randomly selected from each of the 14 Chatsworth units. From each of the 14 schools selected, one class of Grade 7 learners was selected using random sampling. Of the 14 schools selected, 2 schools chose not to participate in the study in view of a decision by their school governing bodies. SPSS version 15.0 (SPSS Inc., Chicago, Illinois, USA) was used to analyse the data. A p value $<0.05$ was considered as statistically significant. Descriptive and summary statistics were used to describe the demographics and responses. In order to assess the association between family structure and various outcomes, cross-tabulation and Pearson's chi square tests were used and row percentages were reported. All the requisite ethical standards regarding confidentiality, voluntary informed consent, anonymity in the reporting of data and doing no harm as a first principle were adhered to. The study was approved by the University of KwaZulu-Natal Research Ethics Committee.

\section{The main objectives of the study were to assess:}

- basic household/family structure in the Chatsworth area, i.e. are they predominantly twoparent, single-parent, male/female, grandparent- or child-headed households;

- the relationship between household structure, the employment status of parents/caregivers and children's access to basic resources;

- the relationship between household structure and children's access to school uniform, other clothing and essential stationery;

- the relationship between household structure and whether children receive adult supervision when they are at home after school; 
- the relationship between household structure and children's access to adequate shelter and food;

- the relationship between household structure and how parent/caregivers handle discipline in respect of children.

\section{Definition of concepts: family and household}

Although the family is the most basic unit of society, with the nuclear family constituting mother and/or father and children as the smallest unit and the extended family (Amoateng, Richter, Makiwane \& Rama, 2004) (which might be inter-generational) constituting this nuclear constellation plus other immediate family members, the concept remains difficult to define. This is because of the many varied family forms, including skip-generation families, reconstituted families, childless families, non-marital cohabitation, child-headed families and gay families. Family groups essentially share the following features: intimacy and interdependence; a relative stability over time; generally defined boundaries that set one family apart from another, with a sense of family identity; and the performance of certain tasks directed toward socio-emotional, moral, material, spiritual and economic functions (Amoateng et al., 2004). Families are generally distinguished by their productive, reproductive and protective functions (Belsey, 2005), connected by kinship, marriage or adoption (Amoateng et al., 2004). Households consist of a population of individuals, not necessarily relatives, residing in the same residential unit (Krekula, 2002:2). The assumption that family equals household structure is not necessarily true, as families may extend across two or three or more households and households may contain two or more families (Cherlin cited in Donahue, Finch, Hack \& Hummer, 2004). For the purpose of this research, however, the concepts family and household were used interchangeably to reflect all members living together and sharing the same residential space.

\section{KEY RESEARCH FINDINGS}

\section{Demographic data}

There were 328 participants in the study. As expected for Grade 7 learners, their mean age was 13.1 years (SD 0.67 years) with a range from 12 to 17 years. The maximum age of 17 years is unusual and could contribute to lower self-esteem and to issues of bullying and stigmatisation, as reflected in prior research (Govender, 2007). In a school-based study into bullying and violence, Govender (2007) found that older children were more prone to experience lower selfesteem and to engage in bulling of younger children on account of their own poor performance and repeated failures.

There were slightly more males than females in the study (52.8\% males and $47.2 \%$ females). As expected in view of the historical legacy described above, most respondents were Indian $(67.7 \%)$, followed by Blacks $(30.7 \%)$. There were very few Coloured and White respondents.

\section{Household and family structure}

Table 1 reflects that having both a mother and father living with the child in a nuclear system was the predominant household structure $(63.8 \%)$. This was followed by $13 \%$ having a mother only, $6.8 \%$ with mother and grandparents only, and $2.8 \%$ with grandparents only. 


\section{TABLE 1}

ADULTS WHOM CHILDREN LIVED WITH: N = 323

\begin{tabular}{|l|c|c|}
\hline & Frequency & Percent \\
\hline Mother and father & 206 & 63.8 \\
\hline Mother only & 42 & 13.0 \\
\hline Mother and Grandparents & 22 & 6.8 \\
\hline Grandparents Only & 9 & 2.8 \\
\hline Other Relatives & 9 & 2.8 \\
\hline Both Parents and Grandparents & 8 & 2.5 \\
\hline Mother and Step-parent & 6 & 1.9 \\
\hline Foster Parent & 4 & 1.2 \\
\hline Mother, Step-parent and Grandparents & 4 & 1.2 \\
\hline Father and Step-parent & 3 & 0.9 \\
\hline Father only & 2 & 0.6 \\
\hline Step-parent & 2 & 0.6 \\
\hline Both Parents and Relatives & 2 & 0.6 \\
\hline Father and Grandparents & 1 & 0.3 \\
\hline Parents, Step-parents and Grandparents & 1 & 0.3 \\
\hline Mother and Other Relatives & 1 & 0.3 \\
\hline Foster Parents and Other Relatives & 1 & 0.3 \\
\hline Total & $\mathbf{3 2 3}$ & $\mathbf{1 0 0}$ \\
\hline
\end{tabular}

It is unfortunate that the above cannot be compared with prior research. As far as we are aware, this is the first study into household and family structure in the Chatsworth area. There are assumptions - based on statistics from welfare organisations and generalisations in the media about the impact of HIV/AIDS and divorce - that the two-parent family structure is being replaced by single-parent, grandparent-headed or other alternative family structures. Almost $64 \%$ of the children in this study reported living with a two-parent nuclear family, with a further 3\% living with both parents in an extended family system. Reflective of national trends, a small minority $(0.6 \%)$ lived with their fathers only, compared with $13 \%$ who lived with mothers only. It is possible that if this study had been conducted 10-15 years ago the results may have been different, showing a higher percentage of children living with both parents, whether in nuclear or extended family systems. The population profile of Chatsworth has been changing over the years, reflecting more racial diversity compared with earlier time times, when it was predominantly Indian. There is also evidence of the growing incidence of divorce and HIV/AIDS that influence family structures. Dilraj, Abdool Karim and Pillay (2007) assert that while African Black women are most vulnerable to HIV infection and the high HIV/AIDS statistics that we read about generally refer to the African Black population, HIV/AIDS does have a foothold in the Indian population. The concern, they argue, is how rapidly it will spread. Dilraj et al. (2007) studied HIV prevalence among Indian and Coloured women. Four ante- 
natal clinics were chosen: one in Chatsworth; two in Phoenix and one in Wentworth; while Chatsworth and Phoenix are predominantly Indian areas, Wentworth is a predominantly Coloured area. They found a $1.1 \%$ prevalence rate among Indians and $4.4 \%$ among Coloured ante-natal clinic attenders, thus challenging the myth that HIV/AIDS is a "black" disease in South Africa. Also, the Chatsworth Hospice had 340 patients in its care at the end of March 2008. Of these, 140 had AIDS.

According to StatsOnline (2005), in 2002 a total of 31370 divorces occurred in South Africa. In 1999 the African, Indian, White and Coloured groups made up 18.4\%; 5.3\%; 39.9\% and 1\% respectively. This pattern had changed by 2008 - the incidence of divorce among the African, Indian and Coloured groups increased to 35\%; $6.2 \%$ and $3.1 \%$ respectively, while the incidence among Whites decreased to 32.8\%. (The South African Divorce Rate, cited in Preller, 2010). While the population profile of Chatsworth has been changing over the years, the results might also reflect a geographic bias as the area is still predominantly Indian. This is significant in the South African context as race, as discussed below, is an important determinant of family structure.

According to Denis and Ntsimane (2006), among large sections of the population, particularly among the poor, marriage no longer governs relations between men and women. Single motherhood, especially among the African Black population, has become the norm. A survey by Denis and Ntsimane (2006) conducted among children of families affected by HIV/AIDS in KwaZulu-Natal found that two thirds of children in this vulnerable group were being raised by single mothers and that these children seldom saw their fathers. This provincial trend is reflective of national norms. According to South Africa's Central Statistics Services (cited in Richter \& Morrell, 2006), about 42\% of children lived with only their mothers in 1998, compared with $1 \%$ who lived with their fathers at that time. Based on household survey data for the period 1993-2002, Posel and Devey (2006) concluded that the proportion of children whose fathers were reported as either dead or absent increased from approximately $43 \%$ in 1993 to $57 \%$ in 2002; thus in 2002 less than half of the children in South Africa were living with their fathers.

The majority of the participants in this study who resided with single parents, mainly mothers only, or with grandparents only were African Black. This is consistent with national trends, which reflects the following statistics (Generalised Household Survey Data, 2002 cited in HSRC, 2004) for children aged 15 years and younger: African Black deceased fathers: 12.8\%; absent (living) fathers: 50.2\%; Coloureds deceased fathers: 7.4\%; absent (living) fathers: 37.2\%; Indians deceased fathers: 5\% absent (living) fathers: 8.4\%; Whites deceased fathers: $2.4 \%$ absent (living) fathers: $10.9 \%$.

The highest percentage of absent (living) fathers is from the African Black community. Various contributing factors for this high rate of "absentee fathers" are suggested in the literature, i.e. the legacy of the apartheid system with the migrant labour system/influx control laws and their destructive effects on the family with husbands and fathers forcibly separated from their families, with fathers/men seeking employment in the urban areas, while the women and children remained on farms. African Black families in South Africa were grievously injured by the colonisation which started with the Dutch slave-owning settlements and continued with the system of apartheid. African customs and traditions were deemed to be savage and heathen. This served to detach Africans from their history, their land and from each other, and was reinforced by the apartheid system (Sachs, 1990). Then there is the system of lobola (bridewealth), where the man pays the family of his fiancée for her hand in marriage, and 
which was aimed at bringing the two families together, fostering mutual respect and confirming the man's financial stability. Historically the lobola payments were done by means of cattle, but nowadays most urban couples use cash. The process of lobola negotiations can be long and complex, and it involves many members from both the bride's and the groom's extended families. Lobola has come to have negative connotations, as young men are hesitant to marry because of the great financial implications, resulting in couples choosing to live together if they lack the financial resources to satisfy the lobola requirements. Thus, Mturi, Xaba and Sekoktla (2005) propose that the lobola should be standardised and be made affordable so that more men will be willing to marry. Apart from attention to such cultural imperatives, Sachs (1990) asserts that the restoration of family life in South Africa has to be a priority and can only be achieved though change in various systems, i.e. in economics through employment practices being revised, land reform, adequate housing and greater access to other basic necessities. These need to be accompanied by deeper democratic practices, enhanced education and open dialogue.

A study by Patrick (2006) in the South African context supports prior research findings about the negative consequences that absent fathers have on children in terms of emotional, social, cognitive and moral development. This attests to the importance of projects such as the "fatherhood project", which was launched in December 2003 in South Africa. This project acknowledges the "absent father syndrome" in South Africa and has programmes to highlight the importance of the roles of fathers (HSRC, 2004).

As reflected in Table 1, the majority of respondents (323) lived with adults; there were 5 reported child-headed households. This is a relatively small number, given the popular discourses on child-headed households in South Africa. It is possible that the geographic location of the study and its predominantly Indian population might have influenced the results. It is also possible, as Brookes, Shisana and Richter (2004) assert, that South Africa may not yet be experiencing the full impact of HIV/AIDS and there still may be time to prepare for an increase in the number of child-headed households. The five children residing without adults were African Black. The literature reflects a trend showing that African children in poor households and children living in informal settlements appear to be most affected by the HIV pandemic (Adato, Kadiyala, Roopnaraine, Biermayr-Jenzano \& Norman, 2005; Bollinger \& Stover, 1999; Brookes et al., 2004). However, the links of this study to the HIV/AIDS pandemic can only be extrapolated from the literature, as children were not asked about the factors that contributed to their living arrangements. Further research is required in this area.

The most common pattern was for the mothers and fathers of the respondents to be married $(65.8 \%)$, followed by $10.8 \%$ where parents were never married, $9.8 \%$ separated and $5.5 \%$ divorced; there were some non-responses. About one-third of the children were from families where parents were not married. The study by Jekielek (1998) provides an insight into the negative impact of parental conflict on children whose families remained intact despite continuous conflict and the results of her study confirm that, despite popular conceptions, children fared better should a divorce or separation occur than living in an environment characterised by continuous parental conflict. Having both parents who are married reflects nothing about the quality of parental relationships or children's relationships with parents. There is a need for more intensive qualitative research into childhood experiences, their access to resources and the coping skills of children in two-parent, single-parent and alternative family households. 


\section{FAMILY STRUCTURE AND EMPLOYMENT}

There was a highly significant association between family structure and employment $(\mathrm{p}<0.001)$. The highest employment rate was found in households with both parents $(84.3 \%)$. The lowest was found in the grandparent-headed households (44.4\%). These results are supported in the literature. In respect of economic stability, Folbre (1994) and Lamb (1982) asserted that in single-parent families income is often inadequate, especially for female single parents, and that single parents face extensive economic discrimination. Lichter (cited in Morgan, 2004) found that poverty among children in America with two full-time earners was virtually non-existent, and that the rise in children's poverty was associated with growth in single-parent families (namely mothers).

According to Statistics South Africa's Labour Force Survey (2007), South Africa had one of the highest unemployment rates in the world and the indicators point to employment rates that remain racially skewed in favour of whites. According to the statistics, while joblessness among white South Africans is $4.6 \%$, it affects $12.7 \%$ of Indians, $19.5 \%$ of Coloureds and $27 \%$ of African Black South Africans aged between 15 and 64 years.

\section{HOUSEHOLD STRUCTURE AND ACCESS TO BASIC RESOURCES}

In terms of access to basic resources, there was no relationship between family structure and access to piped water $(\mathrm{p}=0.746)$ and electricity $(\mathrm{p}=0.805)$, since most households had piped water and electricity regardless of family structure. $2.8 \%$ of the children surveyed did not have piped water in their homes at all. A cross-tabulation revealed that the children who did not have piped water were black and resided in an informal settlement. The issue of lack of access to basic services and the hardships endured on account of electricity and water cut-offs in Chatsworth has been well documented (Desai, 2002). Poor urban townships and rural squatter camps have become battlegrounds in the fight against poor services, as reflected in mass protest action in different parts of South Africa. According to Knight (2001), between 1994 and 2000 1.5 million new electrification connections were established and access to clean running water reached 4 million more people. Pre-paid meters are used for most of these connections. However, many people have been unable to afford payment for these services. Knight (2001) reports that a survey by USAID found that South Africans were willing though unable to pay for services.

\section{HOUSEHOLD STRUCTURE AND SPACE}

There was a significant association between family structure and space in the home $(\mathrm{p}<0.001)$. The households with both parents present were most likely to have enough space, while the grandparent-headed households were the least likely. Inadequate and poor housing remains one of the key challenges in post-apartheid South Africa. The unrest over housing reflects the division between those who have benefited most from democracy and those who have been left behind. Access to a bathroom was also affected by family structure ( $p<0.001)$, with households with both parents most likely to have access and single-parent and step-parent households least likely. A cross-tabulation of results revealed that those children who did not have access to a bathroom were black and from an informal settlement. Poor environments such as these present the greatest risk for children in terms of abuse and neglect (Brookes et al., 2004; Donahue et al., 2004). 


\section{HOUSEHOLD STRUCTURE AND HEALTH SERVICES}

Being taken to a clinic when sick was significantly more common in grandparent-headed households $(\mathrm{p}<0.001)$. Being taken to a public hospital when sick was not different among the groups $(\mathrm{p}=0.147)$; neither was being taken to a private hospital $(\mathrm{p}=0.273)$. However, being taken to a private doctor when sick was significantly different between the groups $(\mathrm{p}=0.001)$. Those from both-parent-headed households were most likely to go to a private doctor.

Being taken to a traditional healer when sick was significantly different among the groups $(\mathrm{p}=0.037)$. Those from single-parent and step-parent-headed households were most likely to go to a traditional healer. It should be noted that there might have been under-reporting in respect of these results, as traditional healing is popularly associated with African traditional practices. Whilst Indian participants may seek help from priests, temples, churches and mosques, these may not be construed as traditional healing. There may also have been respondent bias on account of negative connotations associated with traditional healers. Over $60 \%$ of South Africa's population seeks health advice and treatment from traditional healers before visiting a medical doctor. Those who do seek formal health care also continue to visit a traditional healer (AMREF, 2010).

\section{HOUSEHOLD STRUCTURE, PAYMENT OF SCHOOL FEES AND AVAILABILITY OF SCHOOL REQUIREMENTS}

Family structure significantly influenced whether school fees were paid on time $(\mathrm{p}=0.007)$. They were most likely always to be paid on time in both-parent-headed households. There is evidence in the literature that children in two-parent families have greater economic stability and that children in low-income families were likely to complete high school and achieve academically, if their family income increased during the first 5 years of life. Sibling analyses also revealed that economic conditions have the greatest impact during early childhood. Anderson (2003) states that family structure influences schooling outcomes in the following ways: the decisions of adults on the extent of investment in children would determine attendance at school, quality of school attended and expenditure on schooling. He adds that investment decisions are strongly influenced by the composition of the household, with biological parents being the strongest investors in their children. Similarly, children from twoparent households were significantly most likely to have all the stationery requirements for school $(\mathrm{p}=0.010)$.

Family structure did not influence having a school uniform as most had the school uniform regardless of family structure $(\mathrm{p}=0.586)$ - an anticipated finding as school uniforms are compulsory in South African schools. Compulsory school uniforms place additional pressure on parents and caregivers, most of whom are already struggling to provide adequately for themselves and their families.

There was a highly significant association between family structure and having basic clothing $(\mathrm{p}<0.001)$. Again those children with both parents present were most likely to have the basic clothing they required. The least likely were children from foster-parent families.

\section{HOUSEHOLD STRUCTURE AND ADULT SUPERVISION WHEN CHILDREN ARE AT HOME AFTER SCHOOL}

There was a trend which suggested that grandparent-headed households were least likely to leave the children unsupervised. The most likely was the single-parent and step-parent family; $45 \%$ of children from single-parent families and $50 \%$ of children from foster/other 
relatives/step-parent families, according to the data, reside in risk environments, as these children are at home after school without adult supervision. These children are at risk of potential exposure to abuse, early sexual encounters and crime. Tefera, Petersen \& Govender (2006) contend that low socio-economic status and lack of parental supervision and discipline are risk factors for teenage pregnancy and other social problems. They also found that teenage pregnancy increased with the absence of either or both of the parents. Brookes et al. (2004) found that care and protection of South African children both in schools and at home is inadequate and that children are at risk of HIV transmission and abuse in both situations. There is a need for policies and programmes to provide adequate, stimulating and secure after-school care facilities for children, as these are currently lacking in the area.

\section{HOUSEHOLD STRUCTURE AND RECEIVING HELP WITH HOMEWORK}

There was a borderline non-significant association between family structure and getting help to complete homework $(\mathrm{p}=0.061)$. Those who lived with grandparents only were most likely to always get help. There is evidence in the literature that grandparents and extended family members strengthen the coping capacity of vulnerable families. Donahue et al. (2004) state that extended household members, i.e. grandparents/aunts/uncles, are very often assets to parents, especially single parents in undertaking tasks that may otherwise be neglected; also, parent/s experiencing financial/emotional distress may choose to reside with their own parent/s to assist in coping with their own problems. Mokone (2006) found that although grandparents faced challenges as ageing caregivers, with adequate support from the state and NGOs and CBOs, grandparents could be a resource in respect of addressing the child-headed households.

However, it is also evident in the literature that some studies find that extended household members may impact negatively on the mother's parenting behaviour and place a further strain on already scarce resources (Donahue et al., 2004). More research is necessary to adequately explore the role of grandparents and programmes that are required to support their roles.

\section{HOUSEHOLD STRUCTURE AND PROVISION OF FOOD}

Carrying lunch to school was significantly different among the different household structures $(\mathrm{p}<0.001)$. Caution should be used when interpreting this $\mathrm{p}$ value, since the chi square test is invalid as $50 \%$ of cells have expected counts of less than 5 and there are 2 zero count cells. Nevertheless a trend is shown, which suggests that children from households with both parents tend to carry lunch to school, while those from households with single parents or grandparents only are less likely. These results again emphasise the need for strategies to be effected to strengthen the capacities of families to provide food for their families. School feeding schemes are an adequate strategy to ensure that children receive at least one nutritious meal per day. A qualitative investigation into the reasons for not carrying lunch would have provided more information on this aspect.

\section{THE RELATIONSHIP BETWEEN HOUSEHOLD STRUCTURE AND HOW CHILDREN ARE DISCIPLINED}

Being hit was not significantly different among the different family structures $(p=0.082)$. Children with both parents were less likely to be hit and that those with step-parents were most likely to be hit; $28.6 \%$ of the children from single-parent- or step-families reported being hit. Being shouted at was lowest in the grandparent-headed households, but not significantly so $(\mathrm{p}=0.471)$. Being spoken to was not significantly different among the groups $(\mathrm{p}=0.278)$, although it was highest in the households with both parents. 


\section{HOUSEHOLD STRUCTURE AND SENSE OF FUTURE}

There was a significant association between family structure and believing that they will complete high school $(\mathrm{p}=0.030)$. Although most children responded "Yes" to this question, the highest proportion of "No" responses came from children in single-parent-headed households and step-parent households. Prior research reflects inconsistent patterns of the impact of divorce. While Jekielek (1998), for example, concluded that divorce was a better option than children living with parents in conflictual relationships, Simmons, Lin, Gordon, Chonger and Lorenz (1998) found a higher incidence of adjustment problems among children of divorce compared with those in two-parent families. Similarly, Ross and Mirowsky (cited in Morgan, 2004) found that children of divorce were more likely to experience unhappy relationships, marry young, attain lower academic achievements and have higher levels of mistrust which predisposed them to distress in later life.

There was no association between family structure and what the children wanted to do after school ( $\mathrm{p}=0.331)$. These results are positive as, irrespective of family structure, the majority of the children indicated a desire to study after completion of secondary school. This might be reflective of their resilience, their positive outlook about the future and the need to see themselves as successful.

\section{HOUSEHOLD STRUCTURE AND HANDLING OF DISCIPLINE}

The results of the study revealed that children with both parents were less likely to be hit and that those with step-parents were most likely to be hit; $28.6 \%$ of the children from single-parent or step-families reported being hit. Article 19 of the United Nations Convention on the Rights of the Child stipulates that the government and parents have a responsibility to protect children from all types of abuse. Education and awareness programmes on corporal punishment are recommended. Children and parents from step- or reconstituted families require supportive services to cope with the challenges of the new family and the stigma attached to these families, as well as with the external pressures that families often have to contend with. These programmes would decrease the vulnerability of step-children and strengthen the coping capacities of both biological and step-parents.

\section{CONCLUSION}

This study has produced important baseline data on the influence of household and family structure on children in the Chatsworth area. To the best of our knowledge it is the first study of this nature. As the sample was limited to the Chatsworth area, the results do not reflect an equitable distribution of learners in terms of demographic characteristics, particularly race, in South Africa; the majority of the participants were Indian (67.7\%), followed by African Black $(30.7 \%)$.

It should be noted that children living with foster parents sometimes consider their foster parents to be their own parents, and thus their understanding of living in a home with mother and father may not necessarily be a correct reflection of their families of origin. This reflects the limitation of the quantitative method, which did not allow for exploration of the responses provided by the participants. Neither did the method allow for any personal narratives of participants. Such qualitative research would contribute to an in-depth understanding of the children's living conditions, a deeper appreciation of the influence of household composition and family structure on quality of life, and an understanding of the socially constructed meanings that children attach to concepts used in the study. 
It is hoped that this study will lead to further research in the area of household and family composition and structure and their impact on children. It would be interesting to repeat this study at, for example, 5-year intervals to chart whether or not family patterns change over time. Given the national concerns about the impact of HIV/AIDS on family and household structure, it would be useful to replicate this study on a more extensive national scale, combined with qualitative research to offset the limitations acknowledged in this study.

Nam (2004:2) asserts that the argument for the decline of the family has not been adequately researched, proposing that despite changes in family patterns over time, the family remained as a functional social institution. Amoateng et al. (2004) concluded that despite the enormous challenges of the migrant labour system and the devastation of the HIV/AIDS pandemic, most South Africans usually reside with family members. The results of the current study support the assertions of Nam (2004) and Amoateng et al. (2004). Nevertheless, it is a concern that about a third of the children in this study - the majority of whom were African Black - were growing up in the absence of both parents. The results of this study and the literature both nationally and internationally reflect a relationship between growing up with both parents and greater investment in children's education, health and overall wellbeing. There is a need for the development and implementation of family-centred policies that include healthy and viable alternatives to the absence of both parents, as this is a growing reality in the South African context. Such policies must take into account the structural barriers on peoples' lives, as advocated by Sewpaul (2005).

\section{REFERENCES}

ADATO, M., KADIYALA, S., ROOPNARAINE, T., BIERMAYR-JENZANO, P. \& NORMAN, A. 2005. Children in the shadow of AIDS: studies of vulnerable children and orphans in three provinces in South Africa. Washington DC: IFPRI. [Online] Available: www.ifpri.org/sites/default/files/themes/hiv/pdf/adatoetal2005.pdf [Accessed: 08/01/2010].

AMOATENG, A.Y., RICHTER, L.M., MAKIWANE, M \& RAMA, S. 2004. Describing the structure and needs of families in South Africa: towards the development of a national policy framework for families. Cape Town: Human Sciences Research Council.

AMREF. 2009. Traditional Healers - South Africa. African Medical and Research Foundation. [Online] Available: http://kenya.amref.org/what-we-do/traditional-healers-southafrica/ [Accessed: 15/11/2009].

ANDERSON, K.G. 2003. Family structure, schooling outcomes and investment in education in South Africa A Population Studies Center Research Report. [Online] Available: Www.lsr.umich.edu/pubs/pdf [Accessed: 21/01/2010].

BELSEY, M. 2005. AIDS and the family: policy options for a crisis in family capital. New York: United Nations.

BOLlinger, L. \& STOVER, J. 1999. Economic impact of AIDS in South Africa. Johannesburg: Futures Group International.

BOND, P. 2005. Elite transition: from Apartheid to Neoliberalism in South Africa. Scottsville: University of KwaZulu-Natal Press.

BROOKES, H., SHISANA, O. \& RICHTER, L. 2004. The National Household HIV Prevalence and Risk Survey of South African Children. Cape Town: HSRC Publishers. 
CHATSWORTHS HOSPICE. [Online] Available: www.chatshospice.co.za/serviceProg.html [Accessed: 21/04/2011].

DENIS, P. \& NTSIMANE, R. 2006. The absent fathers: why do men not feature in stories of families affected by HIV/AIDS. In: RICHTER, L. \& MORRELL, R. (eds) Baba: men and fatherhood in South Africa. Pretoria: HSRC Press.

DENNIS, P. 2006. The crisis of marriage in contemporary South Africa Grace and Truth: A Journal of Catholic Reflection for Southern Africa, 23(1):3-8.

DESAI, A. 2002. "We are the poors": community struggles in post-apartheid South Africa. New York: Monthly Review Press.

DILRAJ, A., ABDOOL KARIM, S.S. \& PILLAY, S. 2007. Challenging racial stereotyping of AIDS in South Africa with prevalence if HIV in pregnant women. [Online] Available: www.findarticles.com/p/.../ai_n28448820/ [Accessed: 21/04/2011].

DONAHUE, D., FINCH, B.K., HACK, K.A. \& HUMMER, R.A. 2004. Household composition, race/ethnicity and maternal reports of child health in the United States. [Online] Available: http://www.prc.utexas.edu/working_papers/wp_pdf/01 [Accessed: 25/05/2009].

FOLBRE, N. 1994. Who pays for the kids? Gender and the structures of Constraint. New York: Routledge.

GORDHAN, H. 2007. The responses of Child Welfare Organisations in KwaZulu Natal to the challenges of HIV/AIDS. Durban: University of KwaZulu-Natal. (Unpublished MA Dissertation)

GOVENDER, M. 2007. An investigation into the phenomena of bullying and violence in secondary schools in Durban (Merebank and Umlazi). Durban: University of KwaZuluNatal. (Unpublished MA Dissertation)

HARPER, C., JONES, N. \& TINCATTI, C. 2009. Opportunities and challenges in promoting policy- and practice relevant knowledge on child rights. Draft background paper prepared for "Children's Rights at a Crossroads Conference", Addis Ababa, Ethiopia.

HART, G. 2002. Disabling globalisation: places of power in post-apartheid South Africa. Pietermaritzburg: University of Natal Press.

HSRC. 2004. The Fatherhood Project. Cape Town, Human Sciences Research Council (HSRC).

JEKIELEK, S. 1998. Parental conflict, marital disruption and children's emotional wellbeing. Social Forces, 76(3):905-935.

KNIGHT, R. 2001. Housing statistics. [Online] Available: www.sharedinterest.org [Accessed: 15/11/2009].

KREKULA, C. 2002. The concept of family from the children's perspective. Paper presented at the CFR session at the International Sociological Association XV TH Congress in Brisbane. [Online] Available: www.soc.uu.se/plugins/pdfdownload.php?id=1201 [Accessed: 14/05/2007].

LAMB, M.E. 1982. Nontraditional families: parenting and child development. USA: Erlbaum. 
MADHAVAN, S. 2004. Fosterage patterns in the age of AIDS: continuity and change. Social Science and Medicine, 58:1443-1454.

MOKONE, J.M. 2006. Challenges experienced by Grandparents raising grandchildren: An exploratory study. Social Work/Maatskaplike Werk, 42(2):187-200.

MORGAN, K. 2004. The family, community and health in the context of economic change. A literature review. [Online] Available: http://cc.bingj.com/cache.aspx?q=kate+ morgan+literature+review\&d [Accessed: 14/05/2007].

MTURI, A.J., XABA, T. \& SEKOKOTLA, D. 2005. Assessment of circumstances facing contemporary families in South Africa. University of KwaZulu-Natal. [Online] Available: www.sds.ukzn.ac.za/default.php [Accessed: 21/01/2010].

NAM, C.B. 2004. The concept of the family: demographic and genealogical perspective.

[Online] Available: www.ncsociology.org/sociationtoday/v22/family.htm

[Accessed: 14/05/ 2007].

PATRICK, L.C. 2006. Boys experience of an absent father - a gestalt therapeutic description. Pretoria: Unisa. (Unpublished MA Dissertation). [Online] Available: Www.uir.unisa.ac.za/bitstream/10500/2479/1/dissertation.pdf [Accessed: 24/06/2010].

PILLAY, A. 2010. The influence of household structure and family composition on the lives of children in the Chatsworth area. Durban: University of KwaZulu-Natal. (Unpublished MA Dissertation)

POSEL, D. \& DEVEY, R. 2006. The demographics of fatherhood in South Africa: An analysis of survey data, 1993-2002. In: RICHTER, L. \& MORRELL, R. (eds) Baba: men and fatherhood in South Africa. Pretoria: HSRC Press.

PRELLER, B. 2010. The South African Divorce Rate. [Online] Available: Www.mydigitallife.co.za/imdex.php?op [Accessed: 21/04/2011].

RICHTER, L. \& MORRELL, R. (eds) 2006. Baba: men and fatherhood in South Africa. Pretoria: HSRC Press.

SACHS, A. 1990. The constitutional position of the family in a democratic South Africa in protecting human rights, Cape Town: Oxford University Press.

SEWPAUL, V. 2005. A structural social justice approach to family policy: a critique of the Draft South African Family Policy. Social Work/Maatskaplike Werk, 41(4):310-322.

SEWPAUL, V. \& HÖLSCHER, D. 2004. Social work in times of Neoliberalism: a postmodern discourse. Pretoria: Van Schaik Publishers.

SIMMONS., R., LIN, K., GORDON, L., CHONGER, R. \& LORENZ, F. 1998. Explaining the higher incidence on adjustment problems among children of divorce compared with those in two parent families. Journal of Marriage and the Family, 61:1020-1033.

STATISTICS SOUTH AFRICA. 2007 Labour Force Survey. [Online] Available: Www.statssa.gov.za [Accessed: 29/07/2008].

STATSONLINE. 2005. Weekly newsletter (Issue No. 37/2005). [Online] Available: www.statssa.gov.za/publications/statkeyfindings.asp?ppn=Report-03-07-01\&sch=3470.

[Accessed: 21/04/2011]. 
TEFERA, A., PETERSEN, I. \& GOVENDER, K. 2006. A comparison of demographic characteristics and family influences in a sample of pregnant and non-pregnant Black African teenagers. Social Work/ Maatskaplike Werk, 42(1):68-78.

TERREBLANCHE, S. 2002. A history of inequality in South Africa 1652-2002. Pietermaritzburg. University of Natal Press.

UNICEF. 1997. Convention on the rights of the child. Cape Town: CTP Books.

UNION OF SOUTH AFRICA. 1950. Group Areas Act, Act No. 41 of 1950. Pretoria: Government Printer.

WHITESIDE, A. \& SUNTER, C. 2000. AIDS: the challenge for South Africa. Cape Town: Human and Rousseau Ltd \& Tafelberg Publishers Ltd.

Prof Vishanthie Sewpaul; School of Social Work and Community Development, University of KwaZulu-Natal; Ms Anitha Pillay, MA candidate, School of Social Work and Community Development, University of KwaZulu-Natal, Durban, South Africa. 